\title{
STRUKTUR KOMUNITAS HUTAN MANGROVE DI TELUK DODINGA, KABUPATEN HALMAHERA BARAT PROVINSI MALUKU UTARA
}

\author{
Oleh \\ Nebuchadnezzar Akbar ${ }^{1}$, Ikbal Marus ${ }^{1}$, Irfan Haji ${ }^{2}$, Suparto Abdullah ${ }^{1}$, Sabaria \\ Umalekhoa ${ }^{1}$, Fardan S Ibrahim ${ }^{1}$, Muhajirin Ahmad ${ }^{1}$, Abjan Ibrahim ${ }^{1}$ dan Alfiansyah \\ Kahar $^{1}$, Irmalita Tahir ${ }^{1}$ \\ ${ }^{1}$ Program Studi IImu Kelautan. Universitas Khairun, Ternate \\ ${ }^{2}$ Lembaga IImu Pengetahuan Indonesia, Ternate \\ Email : nezzarnebuchad@yahoo.co.id \\ Received March 2017 Accepted April 2017
}

\begin{abstract}
ABSTRAK
Mangrove merupakan salah satu ekosistem penting di kawasan pesisir. Pemanfaatan yang berlebihan dapat menurunkan kuantitas dan kualitas ekosistem mangrove. Tujuan penelitian ini adalah mengetahui kondisi ekosistem mangrove berdasarkan struktur komunitas. Pengambilan contoh mangrove, dilakukan dengan menggunakan metode transect quadrant dan "spot check" (Bengen, 2004). Berdasarkan hasil penelitian ditemukan 12 spesis mangrove yang berasal dari 5 famili. Struktur vegetasi hutan mangrove menunjukan nilai tertinggi untuk kategori kerapatan terdapat pada stasiun I yakni dengan nilai $9,50 \mathrm{ind} / \mathrm{m}^{2}$ dan diikuti oleh stasiun II dengan nilai 6,78 ind/ $\mathrm{m}^{2}$ serta nilai terendah terdapat pada stasiun III yaitu $6,56 \mathrm{ind} / \mathrm{m}^{2}$. Struktur komunitas hutan mangrove di Teluk Dodinga berdasarkan indeks ekologi (nilai kerapatan, frekuensi jenis, tutupan dan nilai penting) cukup baik, sedangkan keanekaragaman spesies mangrove termasuk dalam kategori sedang. Secara umum kondisi lingkungan masih sesuai dengan kriteria habibat mangrove.
\end{abstract}

Kata kunci: Struktur komunitas, ekosistem, mangrove, Teluk Dodinga.

\begin{abstract}
Mangroves is important ecosysytem in coastal area. The high exploration could reduce the quality and quantity of mangrove ecosystem. The objective of this study was to known the structure community of mangrove in Dodinga Bay, North Halmahera. Transect quadrant and spot check method were used in this study. The results found 12 specieses from 5 families of mangroves. The higest density of mangrove was founded in station $\left(9,50 \mathrm{ind} / \mathrm{m}^{2}\right)$. The density of mangrove in station II was $6,78 \mathrm{ind} / \mathrm{m}^{2}$, and the lowest density of mangrove was in station III $(6,56$ ind $/ \mathrm{m}^{2}$ ). The stucture comunity of mangrove based on ecology factors (density, frequency, persent cover and value significant) were chategoryzed into moderate condition, whereas mangrove biodiversity was chategoryzed into medium. The ecology conditions in area study were support for mangrove.
\end{abstract}

Keywords: community structure, ecosystem, mangrove, Dodinga bay. 


\section{PENDAHULUAN}

Kabupaten Halmahera Barat merupakan kabupaten/kota yang memiliki potensi sumberdaya pesisir dan laut. Desa Dodinga terdapat teluk yang menyediakan potensi sumberdaya pesisir dan laut, teluk terbut ialah Teluk Dodinga. Teluk ini memiliki tiga ekosistem pesisir yang lengkap yaitu mangrove, lamun dan terumbu karang. Ketiga ekosistem ini saling terkait antara satu dengan yang lain. Sumberdaya ekosistem mangrove di teluk ini terdistribusi hampir merata disetiap bagian pesisir. Hal ini tentunya memberikan manfaat bagi masyarakat sekitar baik secara ekologi, ekonomi dan sosial-budaya.

Potensi ekosistem mangrove di Teluk Dodinga memberikan gambaran adanya peluang untuk mengembangkan daerah ini menjadi tempat ekowisata mangrove. Selain dari segi ekologi, ditinjau dari aksesibilitas sangatlah mudah untuk mencapai lokasi. Konversi penggunaan ekosistem menjadi tempat wisata ini bisa berguna untuk masyarakat sekitar dan wisatawan mancanegara. Akan tetapi permasalahan mendasar adalah pertumbuhan penduduk yang semakin meningkat, laju pembangunan perkotaan dan pemukiman, harga bahan bakar minyak yang semakin tinggi akan meningkatkan intensitas pengambilan kayu bakar oleh penduduk, dan kepedulian pemerintah dan masyarakat terhadap kelestarian mangrove masih kurang. Peranan hutan mangrove dalam ekosistem pantai sebagai penyediaan bahan organik, tempat asuhan (nursery ground), tempat bertelur (spawning ground), dan tempat berlindung berbagai biota laut, serta sebagai pelindung pantai dari aktivitas gelombang (Saru, 2009). Selain itu hutan mangrove mempunyai peranan dalam ekosistem yang berfungsi sebagai pelindung terhadap hempasan gelombang dan arus (Tarigan, 2008). Semakin banyak manfaat/ keuntungan ekonomis diperoleh, maka semakin berat pula beban kerusakan lingkungan/ekologis yang ditimbulkannya. Begitu pula sebaliknya, bila semakin sedikit manfaat/ keuntungan ekonomis, semakin ringan pula kerusakan lingkungan yang ditimbulkannya.

Kawasan pesisir Kabupaten Halmahera Barat memiliki keanekaragaman mangrove yang tinggi ini berdasarkan hasil penelitian yang dilakukan di Pulau Sidangoli pada tiga lokasi yakni Desa Dehe, Gam dan Manomadehe (Yunus, 2005; Asman, 2007). Informasi ekosistem mangrove dikawasan pesisir Halmahera Barat juga dilaporkan LIPI (2015), di Pulau Manomadehe, Sidangoli yang menunjukan bahwa ekosistem mangrove memiliki persentase tutupan sangat baik. Penelitian juga dilakukan Akbar et al (2015) diwasan pesisir Sidangoli, Hamahera Barat berdasarkan tingkat kepadatan ekosistem mangrove masuk dalam kategori rendah. Selain itu Bappedas (2010) melaporkan dalam hasil identifikasi dan inventarisasi potensi mangrove di Provinsi Maluku Utara bahwa total luas area ekosistem mangrove di Kabupaten Halmahera Barat adalah 1.971,88 ha. Namun tidak menjelaskan secara keseluruhan tentang stuktur komunitas pada daerah ini, hal ini dapat memberikan pandangan bahwa perlu adanya penelitian terkait yang berlokasi dikawasan pesisir lainnya. Penelitian berkaitan dengan struktur komunitas ekosistem mangrove penting dilakukan, dikarenakan dapat memberikan gambaran tentang status ekosistem mangrove.

\section{Lokasi Sampling}

\section{MATERI DAN METODE}

Penelitian dilaksanakan pada bulan November-Desember 2016 di Teluk Dodinga, Kabupaten Halmahera Barat. Provinsi Maluku Utara dengan tahapan yaitu 
survey awal, pengambilan data lapang, tabulasi data, analisis dan pembuatan laporan.

\section{Teknik Pengambilan Data}

Stasiun penelitian ditetapkan sebanyak 3 stasiun, yang meliputi bagian utara, selatan dan timur. Pengambilan contoh mangrove menggunakan metode transect quadrant (Bengen, 2004). Setiap stasiun transek di tarik tegak lurus dari arah laut ke darat sepanjang 50 meter sebanyak 3 lintasan dengan jarak antara lintasan 20 meter. Pada setiap transek, data vegetasi di cuplik dengan menggunakan 3 kuadrat yang berdekatan $(10 \mathrm{~m} \times 10 \mathrm{~m}$ ) dan dalam kuadrant tersebut di susun 4 kuadrat (5 $\mathrm{m} \times 5 \mathrm{~m}$ ) untuk pengamatan anakan dan 10 kuadrat kecil $(1 \mathrm{~m} \times 1 \mathrm{~m})$. Selain itu juga pengambilan contoh mangrove, juga dilakukan dengan menggunakan metode "spot check" (Bengen, 2004). Metode ini digunakan untuk melengkapi informasi komposisi jenis, distribusi jenis, dan kondisi umum ekosistem mangrove yang tidak teramati pada metode transek-kuadrat.

Data hasil pengambilan mangrove kemudian dicatat dan di masukan kedalam tabel pencatat. Pencatatan data sesuai dengan kategori pertumbuhan mangrove yaitu :

- Kategori pohon : diameter batang $>4 \mathrm{~cm}$

- Kategori anakan : diameter $<4 \mathrm{~cm}$ dan tinggi $>1 \mathrm{~m}$

- Kategori semaian : tinggi $<1 \mathrm{~m}$

Untuk keperluan identifikasi vegetasi mangrove di ambil contoh biologis berupa komponen daun, bunga, dan buah serta diukur lingkaran batang setiap pohon mangrove setinggi dada. Identifikasi tumbuhan mangrove berdasarkan pedoman Noor et al (2012).

\section{Analisis Data}

Analisa data yang digunakan untuk menentukan kondisi hutan mangrove dengan menggunakan analisa kerapatan jenis, frekuensi jenis, luas areal penutupan, nilai penting jenis (Bengen, 2004) dan keanekaragaman jenis Indeks ShannonWinner (Odum 1971; Krebs 1985).

\section{HASIL DAN PEMBAHASAN}

\section{Parameter Lingkungan}

Ekosistem mangrove secara merata terdistribusi diseluruh kawasan Teluk Dodinga. Areal hutan mangrove di ketiga stasiun memiliki substrat lumpur berpasir dan pasir patahan karang. Hasil pengukuran parameter hidrologi menunjukan lingkungan didaerah tersebut sangat sesuai dengan kriteria pertumbuhan mangrove (Tabel 1)

Tabel 1. Hasil Pengukuran Parameter Lingkungan

\begin{tabular}{cclcc}
\hline No & Lingkungan & Parameter & Nilai & Satuan \\
\hline 1 & \multirow{3}{*}{ Perairan } & Suhu & 30 & ${ }^{0} \mathrm{C}$ \\
2 & Salinitas & 34 & $\% \circ$ \\
3 & & pH air & 7 & - \\
4 & \multirow{2}{*}{ Tanah } & pH tanah & 6 & - \\
5 & & Lumpur Berpasir & - & - \\
\hline
\end{tabular}

Kusmana (1995) mengatakan bahwa pertumbuhan mangrove yang baik memerlukan suhu rata-rata minimal lebih besar dari $20{ }^{\circ} \mathrm{C}$. Menurut Aksornkoae 
(1993), mangrove biasanya tumbuh subur di daerah estuaria dengan tingkat salinitas antara 10- 30 ppt. Salinitas merupakan faktor penting dalam pertumbuhan, daya tahan dan zonasi spesies mangrove. Nilai salinitas cenderung tinggi karena lokasi penelitian merupakan pulau kecil yang tidak terpengaruh oleh aliran air tawar dari daratan yang dapat menurunkan nilai salinitas. Berdasarkan standar baku mutu yang telah ditetapkan, toleransi organisme terhadap $\mathrm{pH}$ air berdasarkan Keputusan Menteri Lingkungan Hidup KEP No. 51/MNLH/l/2004, berkisar antara 6.5- 8.5 (MNLH, 2004), sehingga dapat disimpulkan bahwa kisaran $\mathrm{pH}$ air yang ada di lokasi pengamatan masih menunjang kehidupan organisme yang ada.

Nilai $\mathrm{pH}$ sedimen yang cenderung basa pada lokasi penelitian disebabkan karena lokasi sangat dekat dengan pinggiran laut. Menurut Hakim (2009) perombakan bahan-bahan organik oleh kegiatan mikroorganisme akan menghasilkan senyawa asam organik yang berpotensi menurunkan nilai $\mathrm{pH}$. Substrat yang lebih halus memiliki kandungan nutrien yang lebih besar namun oksigen cenderung lebih rendah.

\section{Ketebalan Hutan Mangrove}

Ketebalan hutan mangrove dikawasan teluk Dodinga berdasarkan pengamatan adalah 60 meter (Stasiun I), 130 meter (Stasiun II), 65 meter (Stasiun III) (Gambar 3). Lokasi penelitian stasiun I terletak di bagian selatan pada sisi terluar (tanjung) dari teluk yang memperoleh pengaruh gelombang, arus dan angin. Pada stasiun II terletak dibagian tengah teluk yang terlindung dari hempasan gelombang dan pengaruh arus dan angin. Stasiun III memiliki kemiripan dengan stasiun I dimana terletak pada bagian utara sisi terluar (tanjung) yang juga berhadapan dengan bagian perairan lepas Pulau Halmahera. Jika ditinjau maka, ketiga stasiun memiliki ketebalan yang hampir sama. Hal ini disebabkan karena topografi daratan yang menjorok jauh kearah pantai dan kontur pantai yang landai. Sehingga mangrove memiliki ruang yang besar untuk tumbuh dan berkembang.

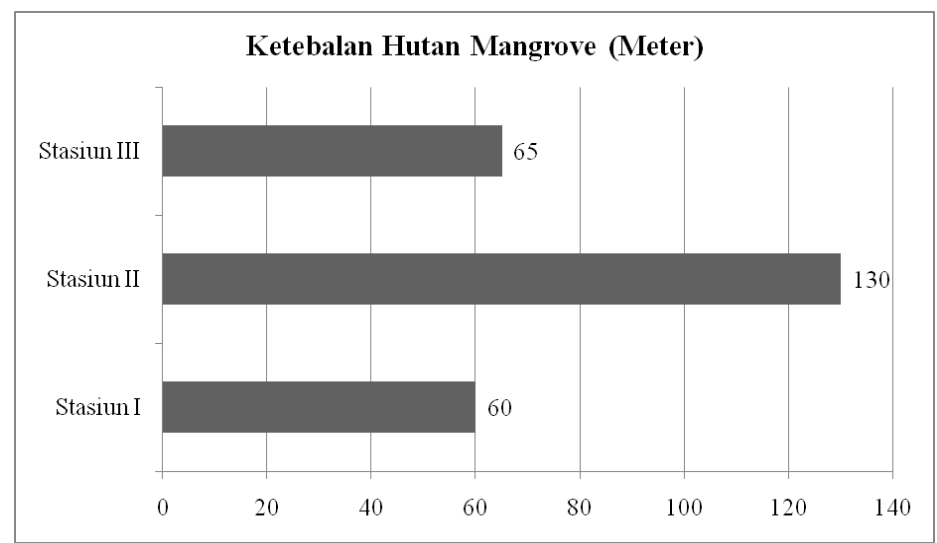

Gambar 1. Ketebalan Hutan Mangrove di Teluk Dodinga, Kab. Halmahera Barat

Wantasen (2002) menjelaskan pantai yang landai memiliki tingkat keanekaragaman ekosistem mangrove yang tinggi dibandingkan dengan pantai yang terjal. Lebih lanjut Akbar (2015) mengatakan pada daerah yang landai memiliki ruang yang luas untuk ditumbuhi oleh mangrove sehingga distribusi jenis mangrove meluas dan melebar.

\section{Komposisi Jenis Mangrove}

Komposisi jenis hutan mangrove dari hasil pengamatan dan identifikasi berdasarkan ciri dari bentuk akar, buah, dan daun diperoleh sebanyak 12 jenis dari 5 
famili (Tabel 2). Kondisi topografi yang landai dan substrat yang sesuai serta dipengaruhi oleh kondisi oseanografi merupakan penyebab tingginya kehadiran jenis mangrove. Meskipun ruang habitat yang terbatas namun tidak memberikan terhadap pola pertumbuhan keadarah darat. Famili Rhizophoraceae memiliki jumlah jenis lebih banyak yaitu 5 jenis dan famili Avicenniacea, Sonneratiaceae dan Meliaceae memiliki masing-masing 1 jenis (Tabel 2).

Tabel 2. Komposisi Jenis Mangrove di Teluk Dodinga

\begin{tabular}{|c|c|c|c|c|}
\hline No & Famili & Spesies & Nama Indonesia & Nama lokal \\
\hline \multirow{6}{*}{1} & \multirow{6}{*}{$\begin{array}{l}\text { Rhizophoracea } \\
e\end{array}$} & Rhizophora & Bakau Merah & \multirow{7}{*}{ Soki-Soki } \\
\hline & & Rhizophora & Bakau & \\
\hline & & Ceriops stagal & Tengar/ M. Kuning & \\
\hline & & $\begin{array}{l}\text { Bruguiera } \\
\text { sexangula }\end{array}$ & Tancang & \\
\hline & & $\begin{array}{l}\text { Bruguiera } \\
\text { gymnorrhiza }\end{array}$ & Tanjang & \\
\hline & & $\begin{array}{l}\text { Bruguiera } \\
\text { cylindrica }\end{array}$ & Tancang & \\
\hline 2 & Meliaceae & $\begin{array}{l}\text { Xylocarpus } \\
\text { granatum }\end{array}$ & M. Apel/Nyirih & \\
\hline 3 & \multirow[t]{2}{*}{ Sonneratiaceae } & Sonneratia alba & Pedada & \multirow[t]{2}{*}{ Posi-Posi } \\
\hline 4 & & Avicennia marina & Pedada & \\
\hline & \multirow{2}{*}{ Avicenniaceae } & Avicennia alba & Api-api & \multirow{3}{*}{ Fika-Fika } \\
\hline & & $\begin{array}{l}\text { Avicennia } \\
\text { officinallis }\end{array}$ & Api-api & \\
\hline 5 & Myrsinaceae & Aegiceras froridum & Semak & \\
\hline
\end{tabular}

Tabel 3. Komposisi Jenis Mangrove di Stasiun I

\begin{tabular}{clcccc}
\hline \multirow{2}{*}{ No } & \multirow{2}{*}{ Jenis } & \multicolumn{3}{c}{ Kategori pertumbuhan } & \multirow{2}{*}{ Jumlah } \\
\cline { 3 - 5 } & & Pohon & Anakan & Semaian & \\
\hline 1 & Rhizophora stylosa & 22 & 9 & 7 & 38 \\
2 & Rhizophora apiculata & 44 & 15 & 22 & 81 \\
3 & Sonneratia alba & 9 & 2 & 4 & 15 \\
4 & Ceriops stagal & 5 & 2 & 1 & 8 \\
5 & Xylocarpus granatum & 4 & 2 & 1 & 7 \\
6 & Avicennia officinallis & 4 & 2 & 2 & 8 \\
7 & Bruguiera sexangula & 4 & 2 & 1 & 7 \\
8 & Avicennia alba & 3 & 1 & - & 4 \\
9 & Bruguiera cylindrica & 2 & 1 & - & 3 \\
& Total & $\mathbf{9 7}$ & $\mathbf{3 0}$ & $\mathbf{3 8}$ & $\mathbf{1 7 1}$ \\
\hline
\end{tabular}


Tabel 4. Komposisi Jenis Mangrove di Stasiun II

\begin{tabular}{clcccc}
\hline \multirow{2}{*}{ No } & \multirow{2}{*}{ Jenis } & \multicolumn{3}{c}{ Kategori pertumbuhan } & \multirow{2}{*}{ Jumlah } \\
\cline { 3 - 5 } & & Pohon & Anakan & Semaian & \\
\hline 1 & Rhizophora apiculata & 16 & 6 & 5 & 27 \\
2 & Sonneratia alba & 12 & 4 & 7 & 23 \\
3 & Aegiceras froridum & 7 & 2 & 1 & 10 \\
4 & Ceriops stagal & 4 & 2 & & 6 \\
5 & Avicennia officinallis & 28 & 5 & 14 & 47 \\
6 & Bruguiera cylindrica & 6 & 2 & 1 & 9 \\
& Total & $\mathbf{7 3}$ & $\mathbf{1 0}$ & $\mathbf{1 3}$ & $\mathbf{1 2 2}$ \\
\hline
\end{tabular}

Tabel 5. Komposisi Jenis Mangrove di Stasiun III

\begin{tabular}{clcccc}
\hline \multirow{2}{*}{ No } & \multirow{2}{*}{ Jenis } & \multicolumn{3}{c}{ Kategori pertumbuhan } & \multirow{2}{*}{ Jumlah } \\
\cline { 3 - 5 } & & Pohon & Anakan & Semaian & \\
\hline 1 & Rhizophora apiculata & 27 & 11 & 17 & 55 \\
2 & Rhizophora stylosa & 17 & 8 & 14 & 39 \\
3 & Sonneratia alba & 13 & 3 & 2 & 18 \\
4 & Ceriops stagal & 4 & 2 & & 6 \\
& Total & $\mathbf{6 1}$ & $\mathbf{1 9}$ & $\mathbf{3 3}$ & $\mathbf{1 1 8}$ \\
\hline
\end{tabular}

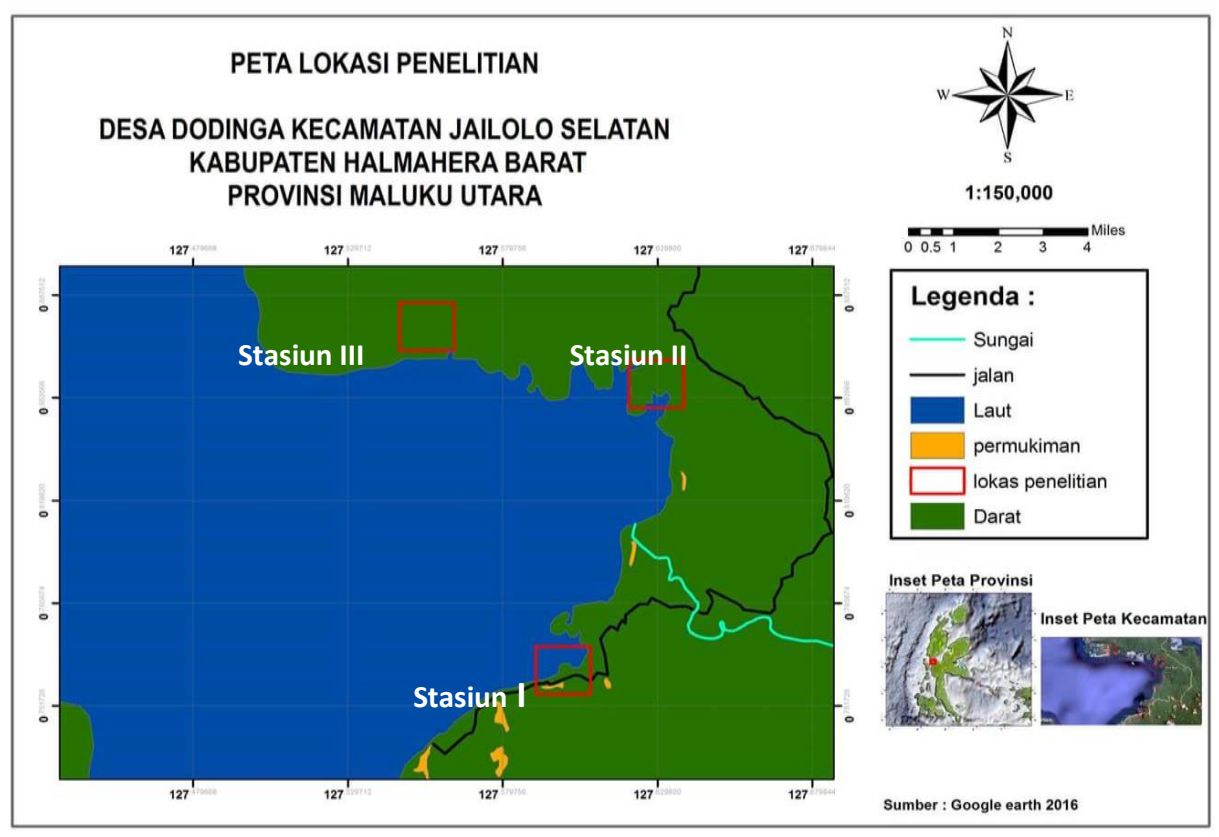

Gambar 2. Peta Lokasi Penelitian

Banyaknya jenis famili Rhizophoraceae yang ditemukan disebabkan kehadiran jenis ini setiap stasiun dan kuadran lebih banyak (Tabel 3,4,5). Adapun substrat yang ditemukan pada lokasi ini didominasi oleh lumpur berpasir, hal ini tentunya 
sangat mendukung famili ini. Hal ini juga dilaporan Akbar et al (2015) di kawasan pesisir Sidangoli Kab. Halmahera Barat.

\section{Struktur Komunitas dan Vegetasi Mangrove}

Struktur vegetasi hutan mangrove menunjukan nilai tertinggi untuk kategori kerapatan terdapat pada stasiun I dan terendah stasiun III yaitu $6,56 \mathrm{ind} / \mathrm{m}^{2}$. Kategori frekuensi jenis ditemukan paling tinggi stasiun I yakni $4,83 \mathrm{ind} / \mathrm{m}^{2}$ dan terendah stasiun III yakni $1,50 \mathrm{ind} / \mathrm{m}^{2}$. Nilai tutupan tertinggi pada stasiun I yaitu 14,23 dan terendah stasiun III yaitu 8. Sedangkan untuk nilai penting adalah $300 \%$ (Tabel 6).

Tingginya nilai kerapatan mangrove pada stasiun I diakibatkan oleh keberadaan substrat yang cocok terhadap pertumbuhan mangrove, selain itu pada lokasi ini aktivitas masyarakat sangat rendah, mangrove dibiarkan tumbuh dan berkembang akibat pemahaman akan pentingnya keberadaan mangrove sebagai habitat ikan dan sumberdaya alam lainnya. Sedangkan pada stasiun II dan III ditemukan kebun masyarakat didekat area mangrove, hal lain yang ditemukan adalah dilokasi tersebut jenis mangrove dengan batang yang sudah besar akan diambil dan dibuat bahan untuk rumah kebun masyarakat.

Tabel 6. Struktur Komunitas Hutan Mangrove per Stasiun

\begin{tabular}{cccc}
\hline Jumlah Total & Stasiun 1 & Stasiun 2 & Stasiun 3 \\
\hline $\mathrm{Di}$ & $9,50 \mathrm{ind} / \mathrm{m}^{2}$ & $6,78 \mathrm{ind} / \mathrm{m}^{2}$ & $6,56 \mathrm{ind} / \mathrm{m}^{2}$ \\
$\mathrm{Rdi}$ & $100 \%$ & $100 \%$ & $100 \%$ \\
$\mathrm{Fi}$ & $4,83 \mathrm{ind} / \mathrm{m}^{2}$ & $2,83 \mathrm{ind} / \mathrm{m}^{2}$ & $1,50 \mathrm{ind} / \mathrm{m}^{2}$ \\
$\mathrm{Fri}$ & $100 \%$ & $100 \%$ & $100 \%$ \\
$\mathrm{Ci}$ & 14,23 & 11 & 8 \\
$\mathrm{Rci}$ & $100 \%$ & $100 \%$ & $100 \%$ \\
$\mathrm{NP}$ & $300 \%$ & $300 \%$ & $300 \%$ \\
\hline
\end{tabular}

\section{Indeks Ekologi Mangrove}

Keseluruhan hasil analisis kerapatan relatif, frekuensi, tutupan dan nilai penting jenis setiap lokasi terdapat pada (Tabel 7, 8 dan 9). Kerapatan jenis tertinggi diperoleh pada jenis Rhizophora apiculata, diduga bahwa pada daerah ini memiliki habitat yang cocok, selain itu juga dipengaruhi oleh rendahnya kegiatan pembabatan mangrove dan kemampuan beradaptasi dengan lingkungan. Hal yang sama juga ditemukan Akbar et al (2015) di pesisir Pulau Sidangoli. Kondisi lingkungan lumpur berpasir akan mendukung kehadiran dan merupakan tempat tumbuh berkembang famili Rhizophoraceae (Noor et al., 2012). Kerapatan jenis merupakan nilai yang menunjukkan banyaknya individu suatu jenis per satuan luas. Makin besar kerapatan suatu jenis, makin banyak individu jenis tersebut per satuan luas (Bengen, 2004; Irwanto, 2006).

Tabel 7. Struktur Komunitas Hutan Mangrove pada Stasiun I

\begin{tabular}{|c|c|c|c|c|c|c|c|c|}
\hline \multirow{2}{*}{ No } & \multirow{2}{*}{ Jenis } & \multicolumn{7}{|c|}{ Indeks Ekologi } \\
\hline & & Di & Rdi & Fi & Fri & $\mathrm{Ci}$ & Rci & NP \\
\hline 1 & $\begin{array}{l}\text { Rhizophora } \\
\text { stylosa }\end{array}$ & 2,11 & 22,22 & 0,83 & 17,24 & 2,67 & 19 & 58,23 \\
\hline 2 & Rhizophora & 4,50 & 47,37 & 1,00 & 20,69 & 3,06 & 21,50 & 89,56 \\
\hline
\end{tabular}




\begin{tabular}{|c|c|c|c|c|c|c|c|c|}
\hline & apiculata & & & & & & & \\
\hline 3 & Sonneratia alba & 0,83 & 8,77 & 0,50 & 10,34 & 3,33 & 23,40 & 42,52 \\
\hline 4 & $\begin{array}{l}\text { Ceriops stagal } \\
\text { Xylocarpus }\end{array}$ & 0,44 & 4,68 & 0,33 & 6,90 & 1,14 & 8,01 & 19,59 \\
\hline 5 & $\begin{array}{l}\text { granatum } \\
\text { Avicennia }\end{array}$ & 0,39 & 4,09 & 0,50 & 10,34 & 1,20 & 8,43 & 22,87 \\
\hline 6 & $\begin{array}{l}\text { officinallis } \\
\text { Bruguiera }\end{array}$ & 0,44 & 4,68 & 0,67 & 13,79 & 1,02 & 7,17 & 25,64 \\
\hline 7 & sexangula & 0,39 & 4,09 & 0,33 & 6,90 & 1,39 & 9,77 & 20,76 \\
\hline 8 & $\begin{array}{l}\text { Avicennia alba } \\
\text { Bruguiera }\end{array}$ & 0,22 & 2,34 & 0,50 & 10,34 & 0,23 & 1,62 & 14,30 \\
\hline 9 & $\begin{array}{l}\text { cylindrica } \\
\text { Total }\end{array}$ & $\begin{array}{l}0,17 \\
\mathbf{9 , 5 0}\end{array}$ & $\begin{array}{l}1,75 \\
100\end{array}$ & $\begin{array}{l}0,17 \\
4,83\end{array}$ & $\begin{array}{c}3,45 \\
66\end{array}$ & $\begin{array}{c}0,19 \\
14,23\end{array}$ & $\begin{array}{l}1,34 \\
\mathbf{1 0 0}\end{array}$ & $\begin{array}{c}6,54 \\
\mathbf{3 0 0}\end{array}$ \\
\hline
\end{tabular}

Tabel 8. Struktur Komunitas Hutan Mangrove pada Stasiun II

\begin{tabular}{|c|c|c|c|c|c|c|c|c|}
\hline \multirow{2}{*}{ No } & \multirow{2}{*}{ Jenis } & \multicolumn{7}{|c|}{ Indeks Ekologi } \\
\hline & & $\mathrm{Di}$ & Rdi & $\mathrm{Fi}$ & Fri & $\mathbf{C i}$ & Rci & NP \\
\hline 1 & $\begin{array}{l}\text { Rhizophora } \\
\text { apiculata }\end{array}$ & 1,50 & 22,13 & 0,33 & 11,76 & 2,55 & 23 & 56,97 \\
\hline 2 & $\begin{array}{l}\text { Sonneratia alba } \\
\text { Aegiceras }\end{array}$ & 1,28 & 18,85 & 0,50 & 17,65 & 2,89 & 26 & 62,65 \\
\hline 3 & froridum & 0,56 & 8,20 & 0,33 & 11,76 & 1,22 & 11 & 31,00 \\
\hline 4 & $\begin{array}{l}\text { Ceriops stagal } \\
\text { Avicennia }\end{array}$ & 0,33 & 4,92 & 0,33 & 11,76 & 0,19 & 2 & 18,40 \\
\hline 5 & $\begin{array}{l}\text { officinallis } \\
\text { Bruguiera }\end{array}$ & 2,61 & 38,52 & 0,83 & 29,41 & 3,12 & 28 & 96,17 \\
\hline 6 & cylindrica & 0,50 & 7,38 & 0,50 & 17,65 & 1,08 & 10 & 34,80 \\
\hline & Total & 6,78 & 100 & 2,83 & 100 & 11,05 & 100 & 300 \\
\hline
\end{tabular}

Tabel 9. Struktur Komunitas Hutan Mangrove pada Stasiun II

\begin{tabular}{llccccccc}
\hline \multirow{2}{*}{ No } & \multirow{2}{*}{ Jenis } & Di & Rdi & Fi & Fri & Ci & Rci & NP \\
\cline { 2 - 8 } & Rhizophora & 3,06 & 46,61 & 1,00 & 37,50 & 2,87 & 35,65 & 119,76 \\
1 & apiculata & & & & & & & \\
2 & Rhizophora stylosa & 2,17 & 33,05 & 0,83 & 31,25 & 2,01 & 24,97 & 89,27 \\
3 & Sonneratia alba & 1,00 & 15,25 & 0,50 & 18,75 & 2,95 & 36,65 & 70,65 \\
4 & Ceriops stagal & 0,33 & 5,08 & 0,33 & 12,50 & 0,22 & 2,73 & 20,32 \\
& \multicolumn{1}{c}{ Total } & 6,56 & 100 & 2,67 & 100 & 8,05 & 100 & 300 \\
\hline
\end{tabular}

Frekuensi jenis menggambarkan kesempatan ataupun kemungkinan dan peluang dapat tumbuh dan ditemukannya suatu spesies dalam suatu areal lokasi yang menjadi areal pengamatan (Akbar et al., 2015). Hutching dan Saenger (2000) mengatakan bahwa kemampuan kompetisi suatu tumbuhan adalah suatu fungsi dari area, aktivitas dan distribusi dalam ruang dan waktu. Nilai frekuensi jenis yang diperoleh memperlihatkan bahwa peluang akan kehadiran mangrove disetiap lokasi sangat besar, sehingga memberikan peluang kestabilan mangrove di lokasi ini. 
Penutupan jenis ini menggambarkan tingkat penutupan jenis mangrove terhadap lahan yang menjadi areal tumbuh mangrove tersebut. Tutupan jenis tertinggi disebabkan karena ukuran lingkar batang yang besar dengan tutupan kanopi yang tinggi. Karakterisktik dan kriteria ini ditemukan pada jenis mangrove Sonneratia alba. Indeks nilai penting jenis mangrove pada setiap lokasi adalah 300, hal ini menunjukan peran setiap spesies mangrove memiliki pengaruh yang besar, selain itu juga berpengaruh terhadap petumbuhan mangrove dalam sutu komunitas. Eksploitasi mangrove, habitat yang cocok dan kondisi perairan yang stabil adalah faktor-faktor yang dapat mempengaruhi besarnya nilai penting (Akbar et al., 2015).

Secara umum ekosistem mangrove di Teluk Dodinga telah mendapatkan ancaman dari manusia. Pada lokasi ini terdapat pelabuhan sebagai sarana penyuplai kapal minyak ke daratan halmahera. Kondisi ini tentunya sangat rentan terhadap kondisi mangrove dikarenakan minyak hasil salinan sering tumpah dan menyebar diperairan sekitar hingga akan mengendap di akar mangrove. Hal ini tentunya memberikan efek biologi terhadap pertumbuhan dan kemampuan bertahan mangrove di alam. Jika dibiarkan secara terus menerus, bukan tidak mungkin akan menyebabkan kematian terhadap yang cukup tinggi. Selain itu penduduk sering memanfaatkan mangrove yang telah dengan diameter batang yang besar untuk digunakan sebagai bahan bangunan ataupun kayu bakar.

\section{Keanekaragaman Jenis Mangrove}

Analisis keanekaragaman jenis mangrove setiap stasiun menunjukan bahwa stasiun 1 dan 2 memiliki nilai sama dan berbeda dengan stasiun 3 (Gambar 04). Berdasarkan kriteria keanekaragaman jenis, maka ketiga stasiun masuk dalam kriteria keanekaragaman sedang. Penelitian dengan hasil yang sama juga ditemukan Mukhlisi et al (2013) di Desa Sidodadi Kecamatan Padang Cermin Kabupaten Pesawaran, Provinsi Lampung. Keanekaragaman jenis suatu komunitas akan tinggi jika komunitas itu disusun oleh banyak jenis dan tidak ada spesies yang mendominasi. Sebaliknya, suatu komunitas memiliki nilai keanekaragaman jenis yang rendah, jika komunitas itu disusun oleh sedikit jenis dan ada species yang dominan (Indriyanto, 2006). Nilai keanekaragaman yang diperoleh memperlihatkan adanya variasi antar stasiun, hal ini disebabkan komposisi dan jumlah jenis yang ditemukan setiap lokasi berbeda-beda. Hal lain yang dapat mempengaruhi keanekaragaman jenis dan pertumbuhan mangrove adalah suplai air tawar dari sungai yang bermuara ke laut serta kesesuaian habitat setiap jenis terhadap iklim dan kondisi geografis pesisir (Duke et al., 1998).

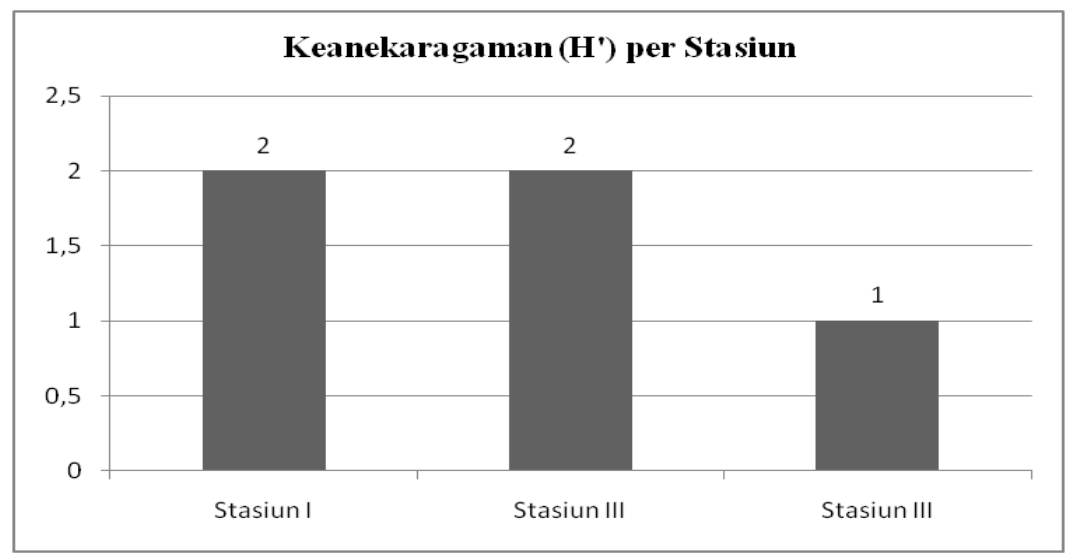

Gambar 04. Keanekaragaman Mangrove per Stasiun 
Keseluruhan nilai keanekaragaman jenis menunjukan adanya variasi antar spesies (Gambar 5). Hasil perhitungan nilai indeks keanekaragaman spesies mangrove pada setiap stasiun, diperoleh nilai keanekaragaman spesies tertinggi dari 9 spesies yang ditemukan adalah Rhizophora apiculata dan terendah Bruguiera cylindrica . Pada stasiun II ditemukan 6 spesies dengan keanekaragaman tertinggi diperoleh Avicennia officinallis terendah ditemukan pada Ceriops stagal yaitu 0,15. Sedangkan untuk stasiun III keanekaragaman tertinggi dari dari 4 spesies yang ditemukan diperoleh Rhizophora stylosa dan terendah pada spesies Ceriops stagal yaitu 0,15 . Nilai indeks keanekaragaman jenis mangrove ini sedikit lebih tinggi dari Pulau Sebatik, Kalimantan Timur dengan $\mathrm{H}^{\prime}=0,64-1,55$ (Ardiansyah et al., 2012) dan kawasan hutan mangrove di Banyuasin, Sumatera Selatan dengan $\mathrm{H}^{\prime}=0,34-0,88$ (Indriani et al., 2009). Nilai keanekaragaman suatu komunitas sangat bergantung pada jumlah jenis dan jumlah individu yang terdapat pada komunitas tersebut.
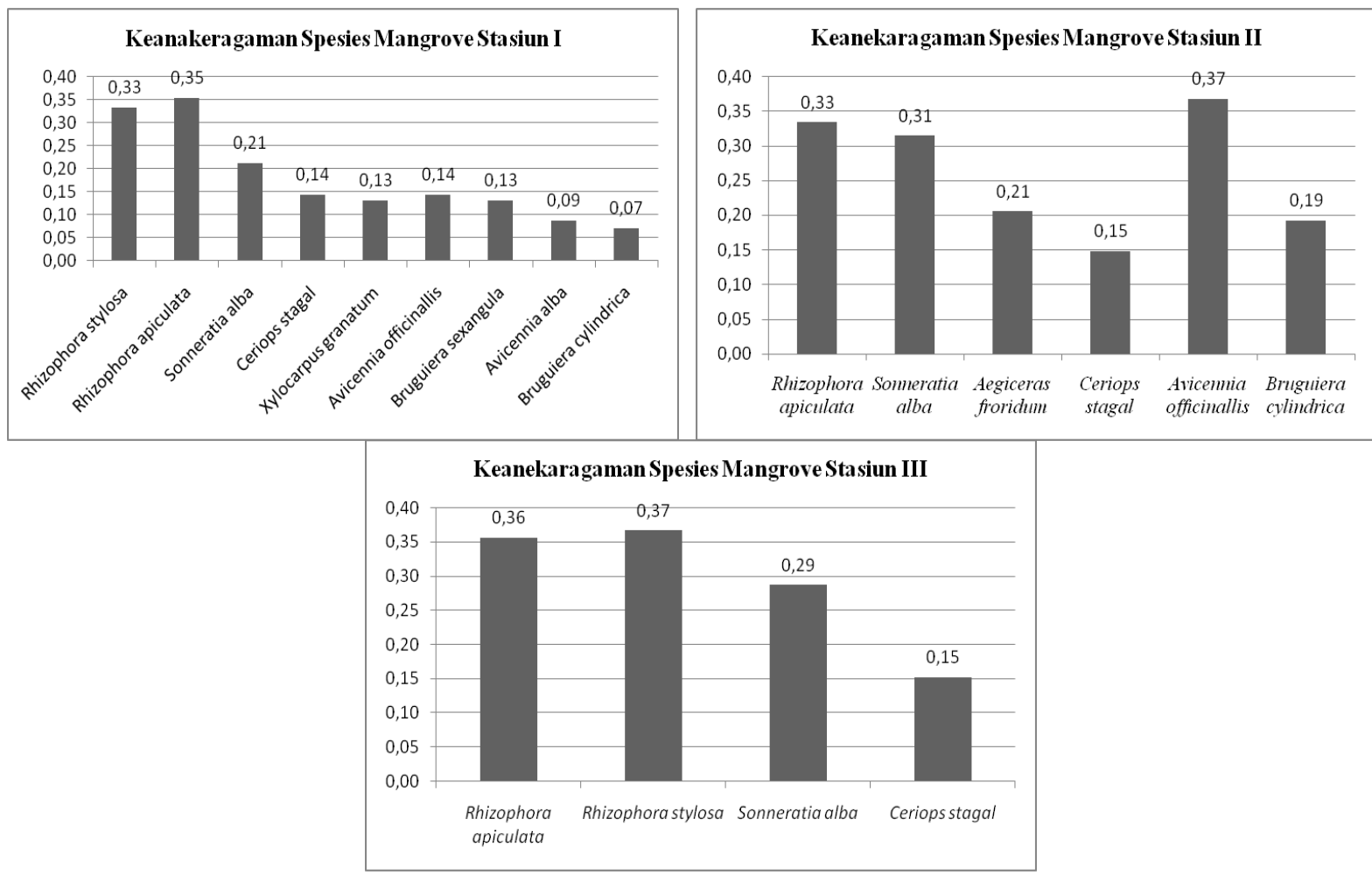

Gambar 05. Keanekaragaman Spesies Mangrove Stasiun I,II dan III

Secara alami keanekaragaman jenis hutan mangrove memang lebih rendah bila dibandingkan hutan tropis namun memiliki struktur dan fungsi yang mampu mempertahankan hidupnya pada lingkungan ekstrim di zona pasang surut (Duke et al., 1998). Ekosistem mangrove juga memiliki produktivitas primer yang tinggi namun dapat dengan mudah berubah bila ada gangguan terutama yang bersifat antropogenik. Tinggi rendahnya keanekaragaman juga dipengaruhi oleh aktivitas antropogenik yang terjadi. Sebagian besar perubahan vegetasi hutan mangrove disebabkan oleh aktivitas antropogenik pada kawasan pesisir (Alongi, 2002; Thampanya et al., 2006).

\section{KESIMPULAN DAN SARAN}


Kehadiran jenis mangrove dilokasi ini sangat tinggi yakni 12 spesies dari 5 famili. Kondisi perairan masih mendukung kehadiran dan pertumbuhan mangrove. Hasil analisis menunjukan struktur komunitas hutan mangrove di Teluk Dodinga berdasarkan indeks ekologi (nilai kerapatan, frekuensi jenis, tutupan dan nilai penting) cukup baik, sedangkan keanekaragaman spesies masngrove termasuk dalam kategori sedang. Perlu suatu pendekatan pada masyarakat untuk membantu memberikan informasi terhadap peran, manfaat dan juga strategi pengelolaan serta pelestarian mangrove kedepan.

\section{UCAPAN TERIMAKASIH}

Penulis mengucapkan terimakasih kepada Fakultas Perikanan dan IImu Kelautan atas dana hibah yang diberikan untuk penelitian ini. Selain itu juga kepada aparatur dan masyarakat Desa Dodinga yang bersedia menuntun dan membantu penulis selama pengambilan data dilapangan.

\section{DAFTAR PUSTAKA}

Akbar, N, A. Baksir, I. Tahir . 2015. Struktur Komunitas Ekosistem Mangrove di Kawasan Pesisir Sidangoli Kabupaten Halmahera Barat, Maluku Utara. Depik Jurnal, Vol 4 (3) : 132-143.

Aksornkoae, S. 1993. Ecology and Management of Mangroves. Bangkok: IUCN Alongi, D.M. 2002. Present state and future of the world's mangrove forests.

Environmental Conservation 29 (3) : 331-349.

Asman, 2007. Studi Pemetaan Ekosistem Hutan Mangrove di Pesisir Pantai Desa Sidangoli Dehe Kecamatan Jailolo Selatan Kabuopaten Halmahera Barat Provinsi Maluku Utara.Skripsi. Jurusan IImu Kelautan. Fakultas Perikanan dan IImu Kelautan Universitas Khairun.Ternate.

Ardiansyah, W.I, R. Pribadi \& S. Nirwan. 2012. Struktur dan komposisi vegetasi mangrove di kawasan pesisir Pulau Sebatik, Kabupaten Nunukan, Kalimantan Timur. Journal of Marine Research 1 (2): 203-215

Balai Pengelolaan Daerah Aliran Sungai (Bapedas) Ake Malamo. 2010. Buku IV (naskah dan data). Rencana teknik rehabilitasi hutan dan lahan daerah aliran sungai (RTk-RHL DAS) ekosistem mangrove dan sempadan pantai wilayah kerja bpdas ake malamo.Ternate.

Bengen, D. G. 2004. Pedoman Teknis Pengenalan dan Pengelolaan Ekosistem mangrove. Pusat Kajian Sumberdaya Pesisir Dan Lautan. IPB. Bogor.

Duke, N.C., M C. Ball \& J.C. Ellison. 1998. Factors influencing biodiversity and distributional gradients in mangroves. Global Ecology and Biogeography Letters 7 (1): 27-47.

Hakim, N. 2009. Penuntun Ringkas Dasar - Dasar Ilmu Tanah. Universitas Andalas: Padang.

Hutching, P \& P. Saenger. 2000. Ekologi mangrove. Laboratorium Ekologi Hutan. Fakultas Kehutanan Institut Pertanian Bogor.Bogor

Indriani, D.P, H. Marisa \& Zakaria. 2009. Keanekaragaman spesies tumbuhan pada kawasan mangrove Nipah (Nypa fruticans Wurmb.) di Kec. Pulau Rimau Kab.

Banyuasin Sumatera Selatan. Jurnal Penelitian Sains12 (3): 1-4

Indriyanto, 2006. Ekologi Hutan. Jakarta: Penerbit PT Bumi Aksara 
Irwanto. 2006. Analisis struktur dan vegetasi komposisi vegetasi untuk pengelolaan kawasan hutan lindung pulau Marsegu Kabupaten Seram Bagian Barat Propinsi Maluku. Tesis. Universitas Gajah Mada. Yogyakarta.

Krebs, C. J. 1985. Experimental Analysis of Distrbution of Abudance. Thrid edition. New York: Harper \& Row Publisher.

Kusmana, C \& Istomo. 1995. Ekologi Hutan. Laboratorium Kehutanan. Fakultas Kehutanan. Intitut Pertanian Bogor. Bogor.

Lembaga IImu Pengetahuan Indonesia. 2015. Survei Baseline Coremap CTI Kondisi Terumbu Karang dan Ekosistem Terkait di Ternate, Tidore dan Sekitarnya, Maluku Utara. Pusat Penelitian Oseanografi. Jakarta.

Mukhlisi, I.G.N \& B.H. Hartuti P. 2013. Keanekaragaman Jenis dan Struktur Vegetasi Mangrove di Desa Sidodadi Kecamatan Padang Cermin Kabupaten Pesawaran, Provinsi Lampung. Prosiding Seminar Nasional Pengelolaan Sumberdaya Alam dan Lingkungan 2013

Noor, Y. R, M. Khazali, \& I.N.N Suryadiputra. 2012. Panduan pengenalan mangrove di Indonesia. Cetakan ke-3. Bogor: Wetlands International Indonesia Programme.

Odum, E. P. 1971. Fundamentals of Ecology. W.B. Sounders Company Ltd. Philadelphia

Saru, A. 2009.Konstibusi Parameter Oseanografi Fisika Terhadap Distribusi Mangrove di Muara Sungai Pangkajene.J. Sains \& Teknologi, Vol 9 No.3 : 210217

Thampanya, U, J.E. Vermaat, S. Sinsakul \& N. Panapitukkul. 2006. Coastal erosion and mangrove progradation of Southern Thailand. Estuarine, Coastal and Shelf Science 68 (2006): 75-85

Tarigan, M.S. 2008. Sebaran Dan Luas Hutan Mangrove Di Wilayah Pesisir Teluk Pising Utara Pulau Kabaena Provinsi Sulawesi Tenggara. Makara, Sains, Vol 12, No. $2:-112$.

Wantasen, A. 2002. Kajian potensi sumberdaya hutan mangrove di Desa Talise Kabupaten Minahasa, Sulawesi Utara. Tesis. Institut Pertanian Bogor.

Yunus, A. H. 2007. Pengukuran Potensi Hutan Mangrove di Desa Gam Kecamatan Jailolo Selatan Kabupaten Halmahera Barat.Skripsi. Jurusan Manajemen Sumberdaya Perairan. Fakultas Perikanan dan Ilmu Kelautan Universitas Khairun.Ternate. 